\title{
EVALUASI PENGENDALIAN INTERNAL SIKLUS PENDAPATAN PADA PT $X$
}

\author{
Aries Wicaksono \\ Accounting and Finance Department, Faculty of Economic and Communication, BINUS University \\ Jln. KH Syahdan No. 9, Palmerah, Jakarta Barat 11480 \\ aries.0202@gmail.com
}

\begin{abstract}
This study aims to evaluate the implementation of internal control in revenue cycle, to identify weaknesses and limitations of internal control, and to suggest improvements as needed. Research was carried out by using several methods. First, the method of data collection was conducted with internal control questionnaires of revenue cycle, interview, and observation. Second, the method of analysis was performed by using COSO internal control framework. Results obtained are internal control in the revenue cycle applied to the company in general is quite good; and there are ineffective implementation of internal control which can lead to the emergence of risks that could harm the company.
\end{abstract}

Keywords: evaluation, internal control, revenue cycle

\begin{abstract}
ABSTRAK
Penelitian bertujuan untuk mengevaluasi penerapan pengendalian internal dalam siklus pendapatan, mengidentifikasi kelemahan dan keterbatasan pengendalian internal, dan menyarankan perbaikan yang diperlukan. Penelitian dilakukan dengan menggunakan beberapa metode. Pertama, metode pengumpulan data yang dilakukan dengan kuesioner pengendalian internal siklus pendapatan, wawancara, dan observasi. Kedua, metode analisis dilakukan dengan menggunakan kerangka pengendalian internal COSO. Hasil yang diperoleh adalah pengendalian internal dalam siklus pendapatan yang diterapkan perusahaan pada umumnya cukup baik; dan adanya implementasi yang tidak efektif dari pengendalian internal yang dapat menyebabkan timbulnya risiko yang dapat membahayakan perusahaan.
\end{abstract}

Kata kunci: evaluasi, pengendalian internal, siklus pendapatan 


\section{PENDAHULUAN}

Perkembangan ekonomi Indonesia yang konsisten dari tahun ke tahun memberikan gambaran bahwa tingkat pertumbuhan dunia usaha juga berlangsung secara konsisten. Sehingga semua entitas bisnis harus terus mengikuti perkembangan agar dapat terus eksis. Kondisi yang demikian menuntut entitas bisnis menjalankan bisnisnya dengan efisien dan efektif sehingga tidak hanya eksis tetapi juga menghasilkan laba atau profit. Laba atau profit bisa dicapai dengan menjaga tingkat penjualan lebih besar daripada biaya yang dikeluarkan dalam menjalankan operasi bisnis. Selain itu produk yang inovatif dan menarik di pasar juga menjadi hal yang sangat berpengaruh.

Untuk mencapai tingkat penjualan yang tinggi serta tingkat biaya yang efektif dan efisien, maka entitas bisnis harus menjaga usahanya agar berlangsung dengan akuntabel serta transparan. Selain itu komitmen karyawan juga harus dijaga agar dapat menjalankan operasional bisnis secara profesional, akuntabel, dan transparan. Untuk itu, dalam menjaga operasional bisnis dijalankan secara profesional, akuntabel, dan transparan, suatu entitas bisnis memerlukan pengendalian internal yang baik serta didukung juga dengan perangkat-perangkat pengendalian internal tersebut.

Pengendalian internal atau internal control dalam suatu entitas bisnis dapat memengaruhi operasional bisnis suatu perusahaan. Pengendalian internal atau internal control yang diterapkan dengan baik dapat menjaga operasional bisnis menjadi lebih akuntabel dan transparan. Hal tersebut dapat terjadi karena setiap aktivitas bisnis dalam entitas terdokumentasi dengan jelas, mengikuti prosedur yang ada, dan mencegah ruang terjadinya penyimpangan. Dengan manfaat yang diharapkan tercipta, maka risiko terhadap kecurangan atau fraud dapat diminimalkan dengan baik. Oleh karena itu, untuk mendukung perusahaan untuk mencapai tujuan perusahaan diperlukan adanya pengelola atau manajemen yang dapat melakukan perencanaan, pengoordinasian serta pengendalian aktivitas yang baik serta dapat mendukung operasional bisnis perusahaan sehingga menjadi lebih efektif, efisien, dan transparan. Selain mempunyai pengendalian internal yang baik, untuk memastikan bahwa aktivitas pengendalian internal telah berjalan dengan baik maka diperlukan pemeriksaan operasional atas aktivitas pengendalian internal yang ada.

Aktivitas yang menjadi tumpuan entitas bisnis untuk menghasilkan laba atau profit adalah aktivitas yang berkaitan dengan penerimaan kas, dalam hal ini lebih dikenal dengan nama siklus pendapatan atau revenue cycle. Semua aktivitas entitas bisnis yang terkait dalam penerimaan kas masuk ke dalam siklus pendapatan atau revenue cycle. Namun pada umumnya siklus pendapatan atau revenue cycle dapat dibagi menjadi tiga kelompok besar yaitu penjualan, pengelolaan piutang, dan penerimaan kas. Ketiga aktivitas ini saling terkait, sehingga jika salah satu di antaranya terjadi masalah, secara langsung akan mengganggu yang lainnya. Menurut Mariani dan Permatasari (2011) diperlukan sistem untuk menangani proses dalam aktivitas penjualan, penerimaan kas, dan pengelolaan piutang agar tujuan pengendalian internal dapat tercapai. Untuk menjaga agar semua aktivitas dalam siklus pendapatan dapat berjalan dengan baik, maka semua aktivitas harus berlangsung sesuai prosedur. Prosedur yang efektif dan efisien merupakan salah satu bentuk dari pengendalian internal yang baik.

PT X merupakan perusahaan yang bergerak di bidang perdagangan alat-alat kesehatan. Alatalat kesehatan yang dijual berupa alat kesehatan yang dijual ke rumah sakit, klinik kesehatan serta apotek. Wilayah pemasaran dan penjualan dari PT X sudah meliputi Pulau Jawa dan sebagian Pulau Sumatera. Penjualan yang dilakukan oleh PT X dilakukan melalui dua cara yaitu melalui penjualan tunai serta penjualan kredit. Proporsi transaksi mayoritas dilakukan secara kredit dengan proporsi antara tunai dan kredit sekitar 65 persen dan 35 persen. Proses pembayaran dilakukan baik dengan menggunakan uang tunai, cek atau bilyet giro, serta transfer. Permasalahan yang ada pada PT X selama ini adalah adanya piutang yang macet dan bahkan sampai pada kondisi tidak tertagih. 
Kemudian sering kali banyak barang diretur oleh konsumen karena kondisi produk yang tidak baik sehingga merugikan perusahaan, dan adanya manipulasi pemberian potongan harga atau diskon kepada pelanggan.

Untuk itu dilakukan penelitian terhadap pengendalian internal siklus pendapatan pada PT X. Adapun penelitian yang dilakukan mempunyai beberapa tujuan, antara lain untuk (1) melakukan evaluasi atas pelaksanaan pengendalian internal pada PT X pada siklus pendapatan, apakah sudah berjalan dengan efektif dan efisien; (2) melakukan evaluasi terhadap kegiatan operasional bisnis pada siklus pendapatan khususnya penjualan, piutang, dan penerimaan kas pada PT X apakah telah dilaksanakan sesuai prosedur dan kebijakan yang berlaku pada PT X; (3) memberikan masukan dan saran kepada manajemen PT X atas kegiatan operasional bisnis pada siklus pendapatan sehingga dapat berjalan dengan lebih efektif dan efisien serta dapat meminimalkan risiko yang ada pada kegiatan operasional siklus pendapatan.

Selain itu, penelitian yang dilakukan terhadap PT X diharapkan dapat memberikan beberapa manfaat. Adapun manfaatnya adalah sebagai berikut: (1) bagi perusahaan, manfaat penelitian bagi perusahaan yaitu membantu perusahaan untuk mengetahui apakah pengendalian internal pada siklus pendapatan yang berlangsung selama ini sudah berjalan dengan baik serta dapat meningkatkan efektivitas dan efisiensi dari proses pengendalian internal yang berjalan; (2) bagi penelitian, memberikan gambaran bagi penelitian wawasan yang lebih luas mengenai proses pengendalian yang berjalan pada siklus pendapatan pada perusahaan; (3) bagi pihak lain, sebagai sarana yang informatif serta menjadi pengembangan pihak lain untuk melakukan penelitian yang lebih lanjut.

\section{Tinjauan Literatur}

Pengertian mengenai pengendalian internal menurut Arens, Elder, dan Beasley (2012) adalah sistem yang terdiri dari kebijakan dan prosedur yang dirancang untuk memberikan manajemen jaminan yang wajar bahwa perusahaan mencapai tujuan dan sasarannya. Sedangkan menurut Bodnar dan Hopwood (2010), pengendalian internal adalah suatu proses yang dirancang untuk menyediakan keyakinan yang rasional atas tercapainya tujuan reliabilitas laporan keuangan, efektivitas dan efisiensi operasi perusahaan, dan kesesuaian organisasi dengan aturan regulasi yang ada. Menurut Weygandt, Kimmel, dan Kieso (2011) pengendalian internal terdiri dari semua metode yang terkait dan tindakan yang diambil dalam sebuah perusahaan untuk menyelamatkan asset-assetnya, meningkatkan catatan pembukuan yang terpercaya, meningkatkan efisiensi operasi dan memastikan kepatuhan terhadap hukum dan peraturan. Berdasarkan definisi tersebut, pengendalian internal dapat disimpulkan sebagai sistem yang terdiri dari metode, kebijakan dan prosedur yang digunakan perusahaan untuk menyelamatkan aset-asetnya, meningkatkan catatan pembukuan yang terpercaya, menjaga reliabilitas laporan keuangan, memastikan efektifvitas operasional, meningkatkan efisiensi operasi dan memastikan kepatuhan terhadap hukum dan peraturan.

Komponen pengendalian internal yang lazim digunakan adalah Committee on Sponsoring Organization (COSO). Seperti yang dikemukakan oleh Romney dan Steinbart (2009) bahwa komponen dari pengendalian internal atau internal control COSO terdiri dari: (1) lingkungan pengendalian (control environment) yang menetapkan suasana suatu organisasi, yang memengaruhi kesadaran akan pengendalian dari orang-orangnya; (2) penilaian risiko (risk assessment) merupakan pengidentifikasian dan analisis entitas mengenai risiko yang relevan terhadap pencapaian tujuan entitas, yang membentuk suatu dasar mengenai bagaimana risiko harus dikelola; (3) aktivitas pengendalian (control activities) yang merupakan prosedur yang membantu meyakinkan bahwa perintah manajemen telah dilaksanakan; (4) informasi dan komunikasi (information and communication) yang merupakan pengidentifikasian, pengungkapan, dan pertukaran informasi dalam suatu bentuk dan kerangka waktu yang membuat orang mampu melaksanakan tanggung jawabnya; (5) 
pemantauan (monitoring) yang merupakan suatu proses yang menilai kinerja pengendalian internal pada suatu waktu.

Kemudian batasan-batasan dalam pengendalian internal seperti yang dikemukakan oleh Boynton dan Johnson (2006) yaitu sebagai berikut. Pertama, kesalahan dalam mempertimbangkan (poor judgement); terkadang manajemen dan personel lainnya dapat melakukan pertimbangan yang buruk dalam membuat keputusan bisnis atau dalam melaksanakan tugas rutin karena informasi yang tidak mencukupi, keterbatasan waktu, atau prosedur lainnya. Kedua, gangguan (breakdown); gangguan dalam melaksanakan pengendalian dapat terjadi ketika personel salah memahami instruksi atau yang akhirnya mengakibatkan suatu kecerobohan, kebingungan, atau kelelahan. Perubahan sementara atau permanen dalam personel atau dalam sistem atau prosedur juga dapat berkontribusi pada terjadinya gangguan. Ketiga, kolusi (collusion); individu yang bertindak sama, seperti karyawan yang melaksanakan suatu pengendalian penting bertindak bersama dengan karyawan yang lain, konsumen atau pemasok, dapat melakukan sekaligus menutupi kecurangan sehingga tidak dideteksi oleh pengendalian internal. Keempat, pengabaian oleh manajemen (management override); manajemen dapat mengakibatkan kebijakan atau prosedur tertulis tujuan tidak sah seperti keuntungan pribadi atau status ketaatan. Praktik pengabaian termasuk membuat penyajian yang salah dengan sengaja kepada auditor dan lainnya, seperti menerbitkan dokumen palsu untuk mendukung pencatatan transaksi penjualan fiktif. Kelima, biaya lawan manfaat (cost versus benefit); biaya pengendalian internal suatu entitas seharusnya tidak melebihi manfaat yang diharapkan untuk diperoleh. Pengukuran yang tepat baik dari biaya dan manfaat biasanya tidak memungkinkan, manajemen harus mengestimasikan sendiri baik secara kuantitatif maupun kualitatif dalam mengevaluasi hubungan antara biaya dan manfaat.

Untuk mengevaluasi suatu pengendalian internal maka menurut Agoes (2012) dapat menggunakan beberapa instrumen antara lain: (1) Internal Control Questionnaire (ICQ), instrumen ini biasanya digunakan oleh KAP untuk mengevaluasi pengendalian internal dari kliennya. Instrumen ini digunakan karena lebih sederhana dan praktis. (2) Flowchart (bagan arus), instrumen ini biasanya digunakan untuk menggambarkan proses bisnis dalam suatu unit usaha. Auditor yang menggunakan flowchart merupakan auditor yang sudah terlatih, dengan menggunakan flowchart kelemahankelemahan yang ada lebih mudah untuk dianalisis. (3) Uraian Cerita (Narrative), instrumen ini biasanya digunakan untuk menggambarkan proses bisnis dari suatu organisasi yang memiliki proses bisnis yang sederhana.

Siklus pendapatan, atau revenue cycle, Boynton dan Johnson (2006) menyatakan bahwa siklus pendapatan (revenue cycle) perusahaan terdiri dari aktivitas-aktivitas yang berkaitan dengan pertukaran barang dan jasa dengan pelanggan dan penagihan pendapatan dalam bentuk kas.Siklus pendapatan adalah penjualan kredit (penjualan yang dilakukan dengan hutang), penerimaan kas (penagihan piutang dan penjualan tunai), dan penyesuaian penjualan (potongan, retur penjualan dan pengurangan harga, serta piutang tidak tertagih (penyisihan dan penghapusan)). Lebih lanjut, menurut Romney dan Steinbart (2009) bahwa fungsi penjualan dan penerimaan kas merupakan satu kesatuan dalam siklus pendapatan atau revenue cycle. Aktivitas yang masuk ke penjualan dapat dibagi dalam beberapa aktivitas yaitu menerima pesanan dari pelanggan, mengirimkan pesanan, menerima pembayaran, menyimpan pembayaran yang diterima, dan menyesuaikan perkiraan pelanggan.

Rangkuman kajian teoretis yang telah dianalisis dapat dilihat pada Tabel 1 sebagai berikut: 
Tabel 1 Rangkuman Kajian Teoretis

\begin{tabular}{|c|c|c|c|}
\hline No & Sumber Teori & Penjelasan & Hubungan Penelitian \\
\hline 1 & $\begin{array}{l}\text { Arens,Elder dan } \\
\text { Beasley (2012) }\end{array}$ & $\begin{array}{l}\text { Pengendalian internal adalah sistem yang } \\
\text { terdiri dari kebijakan dan prosedur yang } \\
\text { dirancang untuk memberikan manajemen } \\
\text { jaminan yang wajar bahwa perusahaan } \\
\text { mencapai tujuan dan sasarannya. }\end{array}$ & $\begin{array}{l}\text { Pengendalian internal yang } \\
\text { dievaluasi terdiri dari } \\
\text { kebijakan dan prosedur }\end{array}$ \\
\hline 2 & $\begin{array}{l}\text { Bodnar Odan Hopwood } \\
\text { (2010) }\end{array}$ & $\begin{array}{l}\text { Pengendalian internal adalah suatu proses } \\
\text { yang dirancang untuk menyediakan } \\
\text { keyakinan yang rasional atas tercapainya } \\
\text { tujuan reliabilitas laporan } \\
\text { keuangan,efektivitas dan efisiensi operasi } \\
\text { perusahaan, kesesuaian organisasi dengan } \\
\text { aturan regulasi yang ada. }\end{array}$ & $\begin{array}{l}\text { Tujuan pengendalian internal } \\
\text { untuk mencapai reliabilitas } \\
\text { laporan keuangan, efektivitas } \\
\text { dan efisiensi operasi } \\
\text { perusahaan dan kesesuaian } \\
\text { organisasi dengan aturan dan } \\
\text { regulasi }\end{array}$ \\
\hline 3 & $\begin{array}{l}\text { Romney dan Steinbart } \\
\text { (2009) }\end{array}$ & $\begin{array}{l}\text { Komponen pengendalian internal COSO } \\
\text { terdiri dari Lingkungan pengendalian, } \\
\text { Penilaian Risiko, Lingkungan } \\
\text { pengendalian, Informasi dan komunikasi, } \\
\text { Pemantauan. }\end{array}$ & $\begin{array}{l}\text { Evaluasi pengendalian } \\
\text { internal dilakukan } \\
\text { berdasarkan Lingkungan } \\
\text { pengendalian, Penilaian } \\
\text { Risiko, Lingkungan } \\
\text { pengendalian, Informasi dan } \\
\text { komunikasi, Pemantauan. }\end{array}$ \\
\hline 4. & $\begin{array}{l}\text { Boynton dan Johnson } \\
\text { (2006) }\end{array}$ & $\begin{array}{l}\text { Batasan dalam pengendalian internal antara } \\
\text { lain poor judgement, breakdown, collusion, } \\
\text { management override, cost versus benefit. }\end{array}$ & $\begin{array}{l}\text { Pengendalian internal yang } \\
\text { digunakan dapat dibatasi } \\
\text { dengan lain poor judgement, } \\
\text { breakdown, collusion, } \\
\text { management override, cost } \\
\text { versus benefit. }\end{array}$ \\
\hline 5. & Agoes (2012) & $\begin{array}{l}\text { Instrumen untuk mengevaluasi } \\
\text { pengendalian internal dapat menggunakan } \\
\text { Internal Control Questionnaire, Flowchart, } \\
\text { dan Uraian Cerita. }\end{array}$ & $\begin{array}{l}\text { Evaluasi dilakukan dengan } \\
\text { menggunakan Internal } \\
\text { Control Questionnaire dan } \\
\text { Uraian Cerita. }\end{array}$ \\
\hline 6. & $\begin{array}{l}\text { Boynton dan Johnson } \\
\text { (2006) }\end{array}$ & $\begin{array}{l}\text { Siklus pendapatan (revenue cycle) } \\
\text { perusahaan terdiri dari aktivitas-aktivitas } \\
\text { yang berkaitan dengan pertukaran barang } \\
\text { dan jasa dengan pelanggan dan penagihan } \\
\text { pendapatan dalam bentuk kas.Siklus } \\
\text { pendapatan adalah penjualan kredit } \\
\text { (penjualan yang dilakukan dengan hutang), } \\
\text { penerimaan kas (penagihan piutang dan } \\
\text { penjualan tunai), dan penyesuaian } \\
\text { penjualan (potongan, retur penjualan dan } \\
\text { pengurangan harga, serta piutang tidak } \\
\text { tertagih [penyisihan dan penghapusan]). }\end{array}$ & $\begin{array}{l}\text { Evaluasi terhadap siklus } \\
\text { pendapatan dilakukan } \\
\text { terhadap komponen dari } \\
\text { siklus pendapatan yaitu } \\
\text { penjualan kredit (penjualan } \\
\text { yang dilakukan dengan } \\
\text { hutang), penerimaan kas } \\
\text { (penagihan piutang dan } \\
\text { penjualan tunai), dan } \\
\text { penyesuaian penjualan } \\
\text { (potongan, retur penjualan } \\
\text { dan pengurangan harga, serta } \\
\text { piutang tidak tertagih } \\
\text { [penyisihan dan } \\
\text { penghapusan]). }\end{array}$ \\
\hline
\end{tabular}

\section{METODE PENELITIAN}

Metode yang digunakan dalam penelitian ini adalah metode deskriptif dan wawancara. Penelitian deskriptif dilakukan dengan meneliti pengendalian internal yang berupa prosedur, kebijakan, dan aturan yang ada pada PT X kemudian mengevaluasinya berdasarkan permasalahan yang ada selama ini terjadi dengan menghubungkannya satu sama lain baik dari sisi prosedur, 
kebijakan serta aturan. Metode wawancara digunakan untuk memperoleh gambaran langsung dari pelaku dalam sistem akuntansi siklus pendapaatan yang ada pada PT X. Selain itu, penelitian menggunakan juga instrumen berupa kuesioner untuk menganalisis pengendalian internal yang ada pada PT X. Dari kedua metode tersebut dapat dihasilkan gambaran permasalahan yang selama ini terjadi dan kendala-kendala untuk mengatasi permasalahan tersebut.

\section{HASIL DAN PEMBAHASAN}

\section{Evaluasi terhadap Pengendalian Internal Fungsi Penjualan pada PT. X}

Evaluasi terhadap pengendalian fungsi penjualan pada PT X dilakukan melalui wawancara dan kuesioner. Evaluasi dilakukan dengan menganalisis proses bisnis pada PT X, terutama yang terkait dengan fungsi penjualan. Setelah dianalisis diperoleh beberapa hal yang sudah memenuhi prinsip pengendalian internal pada fungsi penjualan, yaitu: (a) PT X sudah mempunyai standar operasional prosedur atau SOP yang terkait dengan fungsi penjualan; (b) sebelum dilakukan penjualan staf pemasaran diberikan penjelasan mengenai stok barang di gudang, kemudian dilakukan pengecekan ulang ke gudang saat dilakukan penjualan; (c) dokumen sales order dibuat secara prenumbered dengan aplikasi yang telah tersedia pada fungsi penjualan di PT X; (c) untuk melakukan penjualan secara kredit terhadap pembeli baru, dilakukan prosedur verifikasi terlebih dahulu mengenai profil pembeli yang akan melakukan pembelian secara kredit; (d) adanya pemisahan yang jelas antara tugas manajer penjualan dengan staf pemasaran pada PT X; (e) bagian penjualan mengutamakan pembelian secara tunai atas alat kesehatan yang dijual karena mengurangi kemungkinan adanya piutang tidak tertagih; (f) strategi penjualan telah dikomunikasikan dengan baik kepada seluruh staf yang terkait dengan fungsi penjualan pada PT X; dan (g) dilakukan pengecekan kembali terhadap dokumen penjualan yang telah dicetidak dalam proses penjualan pada PT. X.

Selain pengendalian internal yang telah diterapkan dengan baik di PT X, ditemukan juga beberapa permasalahan terkait proses penjualan, antara lain: (a) dalam hal pengiriman barang tidak dilakukan proses pengecekan kualitas terlebih dahulu, terutama terhadap barang yang dalam satuan dus; (b) adanya ketidakjelasan prosedur penentuan potongan penjualan atau diskon, terutama penjualan dalam jumlah banyak, sehingga staf penjualan sering kali menentukan potongan penjualan tanpa koordinasi dengan manajer penjualan; (c) karena tingginya perputaran barang, sering kali staf penjualan memaksakan untuk tetap melakukan penjualan walaupun stok barang yang akan dijual tidak mencukupi untuk dijual.

\section{Evaluasi terhadap Pengendalian Internal Fungsi Pengelolaan Piutang pada PT X}

Setelah melakukan analisis terhadap fungsi penjualan, penelitian melakukan analisis dalam hal fungsi pengelolaan piutang pada PT X. Setelah melakukan analisis dengan melakukan wawancara dan melalui kuesioner, diperoleh fungsi pengendalian internal yang sudah baik diterapkan di PT X terutama yang terkait dengan fungsi pengelolaan piutang, antara lain: (a) PT X sudah mempunyai Standar Operasional Prosedur atau SOP pada aktivitas yang terkait dengan fungsi pengelolaan piutang; (b) fungsi pengelolaan piutang telah dipisahkan dengan fungsi penjualan dan fungsi penerimaan kas; (c) PT X juga telah mengelola penagihan atas piutangnya berdasarkan umur piutang yang dibuat oleh fungsi pengelolaan piutang; (d) sebelum dilakukan penagihan atas piutang yang akan jatuh tempo, dalam fungsi pengelolaan piutang pada PT X dilakukan pengecekan terhadap piutang yang akan jatuh tempo beserta dokumen pendukungnya seperti sales order dan lain-lain; (e) fungsi pengelolaan piutang juga telah melakukan pemeringkatan terhadap klien dari PT X; pemeringkatan tersebut dilihat dari kelancaran pembayaran piutang pada PT X; peringkat yang ada dibagi menjadi tiga peringkat yaitu sangat lancar, lancar, dan tidak lancar; (f) secara periodik fungsi pengelolaan piutang melakukan 
konfirmasi piutang kepada klien untuk mengecek dan memvalidasi piutang yang tercatat di pembukuan PT X; (g) piutang usaha dicatat ke dalam pembukuan PT X setelah semua dokumen pendukung telah dipenuhi kelengkapan dan keabsahannya.

Adapun pengendalian yang masih belum baik diterapkan pada PT X pada fungsi pengelolaan piutang, antara lain: (a) PT X terkadang demi mencapai target penjualan tidak konsisten dalam melakukan pengendalian penjualan kredit terhadap kliennya yang berperingkat tidak lancar; (b) PT X tidak membuat aturan mengenai batasan pemberian kredit atau credit limit sehingga meningkatkan risiko piutang tidak tertagih; (c) tidak adanya reward berupa insentif jika tingkat pembayaran penjualan kredit pada tingkat yang baik; (d) PT X tidak mencadangkan piutang tidak tertagih sehingga risiko piutang tidak tertagih menjadi lebih tinggi; hal tersebut dibuktikan dengan adanya piutang yang tidak tertagih; (e) data piutang pada PT X yang tersimpan pada storage di server tidak dilakukan backup secara periodik sehingga meningkatkan risiko hilangnya data jika terjadi kondisi yang bersifat force majeure.

\section{Evaluasi terhadap Pengendalian Internal Fungsi Penerimaan Kas pada PT X}

Analisis yang telah dilakukan terhadap fungsi penjualan dan pengelolaan piutang dilanjutkan dengan analisis terhadap fungsi penerimaan kas. Hasil dari analisis terhadap fungsi penerimaan kas diperoleh bahwa beberapa hal yang terkait pengendalian internal terhadap penerimaan kas telah diterapkan dengan baik, antara lain: (a) adanya prosedur bahwa uang yang diterima staf penagihan harus langsung diserahkan ke bagian keuangan pada hari yang sama untuk meminimalkan adanya kecurangan; selain itu jumlah uang yang diterima dikonfirmasi kembali kepada klien yang melakukan pembayaran secara tunai; (b) dalam hal penerimaan kas PT X sudah memiliki standar operasional prosedur atau SOP dalam operasional bisnisnya; (c) jumlah uang yang diterima selalu dilakukan pengecekan dengan jumlah piutang yang seharusnya tertagih dari klien yang sudah melakukan pembayaran dan jatuh tempo; (d) setiap penerimaan uang dibuatkan bukti penerimaan kas dan bukti tersebut dibuat dalam nomor prenumbered baik manual maupun yang dicetak melalui aplikasi di bagian keuangan.

Selain dari pengendalian internal yang telah baik diterapkan di PT X pada fungsi penerimaan kasnya, ada juga yang masih kurang menjadi perhatian pada fungsi penerimaan kas pada PT X, antara lain: (a) perusahaan tidak memiliki tempat penyimpanan uang tunai yang memadai berupa brankas yang cukup memadai dan (b) banyaknya transaksi penerimaan kas secara tunai tidak cukup diantisipasi oleh PT X dengan melakukan penyetoran secara cepat atas uang tunai yang diterima.

\section{Evaluasi Berdasarkan Komponen Pengendalian Internal}

Setelah melakukan analisis dari wawancara, observasi, dan kuesioner yang telah dibuat dapat diambil kesimpulan sementara bahwa pengendalian internal siklus pendapatan atau revenue cycle yang ada pada PT X sudah cukup memadai. Namun memang masih ditemukan kelemahan-kelemahan yang menjadi catatan penting yang harusnya menjadi perhatian bagi manajemen. Selain itu perlu disadari oleh pihak manajemen bahwa pengendalian internal atau internal control pada siklus pendapatan merupakan hal yang sangat penting. Hal itu disebabkan siklus pendapatan atau revenue cycle merupakan hal yang sangat berpengaruh terhadap kinerja keuangan dari suatu entitas bisnis. Tingkat pembayaran atas piutang yang baik akan menunjang kinerja keuangan entitas atau perusahaan secara signifikan.

Permasalahan yang menjadi perhatian dalam pengendalian internal terletak pada ketiga fungsi yang ada pada siklus pendapatan pada PT X yaitu fungsi penjualan, fungsi pengelolaan piutang, dan fungsi penerimaan kas. Poin-poin penting yang menjadi perhatian, antara lain: tingkat retur yang cukup tinggi, masalah pada prosedur pemberian diskon bagi penjualan pada jumlah yang besar, tidak adanya batasan kredit pada klien atau pelanggan yan melakukan transaksi penjualan secara kredit 
dengan PT X, kemudian inkonsistensi yang dilakukan oleh PT X dalam pemberian kredit walaupun mekanisme pemeringkatan telah dibuat dan dijalankan oleh perusahaan.

Komponen pengendalian internal yang digunakan untuk menganalisis pengendalian internal siklus pendapatan pada PT X menggunakan komponen pengendalian internal yang dijelaskan oleh Committee on Sponsoring Organization (COSO). Berikut ini adalah analisis dan pembahasan sesuai dengan komponen-komponen yang ada pada pengendalian internal COSO.

\section{Lingkungan Pengendalian (Control Environment)}

Ada empat hal yang menjadi perhatian dalam komponen lingkungan pengendalian, yaitu integritas dan etika, gaya manajemen, struktur organisasi dan pemisahan wewenang, serta kebijakan terhadap sumber daya manusia. Masing-masing komponen saling memengaruhi satu sama lain.

Yang pertama adalah integritas dan etika. Dalam hal ini PT X sangat menjunjung integritas dan etika. PT X sudah memiliki kode etik karyawan yang telah disepakati antara manajemen dan pihak karyawan. Kode etik ini menjadi panduan karyawan dalam melakukan pekerjaan. Selain itu seluruh karyawan juga dituntut untuk menjaga integritas dengan menjunjung prinsip transparansi dan akuntabilitas yang dijadikan salah satu komponen dalam kode etik di PT X. Kode etik tersebut telah disosialisasikan dengan baik; hal tersebut terbukti dengan adanya pamflet mengenai kode etik di setiap ruangan masing-masing fungsi yang ada pada PT X. Meskipun kode etik telah disosialiasikan dengan baik, tetap ditemukan karyawan yang memang masih belum bisa menjaga etika dan integritas dengan melakukan fraud atau kecurangan dalam hal penagihan atas piutang yang dimiliki klien atau pelanggan.

Yang kedua adalah gaya manajemen. Manajemen PT X berdasarkan hasil wawancara menerapkan prinsip leading by example atau memimpin dengan memberikan contoh. Sebagai pemimpin, maka pemimpin dalam perusahaan dari level tertinggi sampai dengan level subunit terkecil harus memberikan contoh dalam melaksanakan aturan serta kode etik yang ada dalam perusahaan sehingga tidak terjadi kecemburuan karena tidak semua melaksanakan aturan dan kode etik yang ada. Dari sisi keterbukaan, manajemen selalu mengomunikasikan kebijakan yang diambil kepada karyawan dan mengakomodasi aspirasi dari karyawan. Hal itu terlihat dengan adanya komunikasi dengan karyawan jika ada aturan baru yang akan dibuat dan diterapkan.

Yang Ketiga adalah struktur organisasi. PT X memiliki struktur organisasi yang jelas dan lengkap karena mengakomodasi semua fungsi bisnis yang ada pada PT X. Fungsi-fungsi strategis dan bersinggungan telah dipisahkan dengan baik sehingga dapat meminimalkan kemungkinan terjadinya fraud atau kecurangan. Selain itu struktur organisasi PT X juga dijadikan bahan dalam membuat Standard Operasional Procedure (SOP) di PT X. Manajemen juga melakukan kegiatan wisata bersama secara rutin setiap tahun guna menjaga hubungan dengan karyawan dan keluarga karyawan. Selain itu PT X juga mengadakan forum rutin setiap enam bulan dengan karyawan untuk menyerap aspirasi dari semua karyawan.

Yang keempat adalah kebijakan terhadap sumber daya manusia. Dalam hal ini karyawan diperlakukan sebagai mitra bagi perusahaan. Setiap karyawan ditetapkan sesuai dengan profil pendidikan dan pengalaman yang mereka miliki. Karyawan juga diharuskan mengikuti pelatihan yang dilakukan oleh PT X. Pelatihan dilakukan sesuai dengan fungsi dari masing-masing departemen yang ada pada PT X. Selain itu, diberikan juga berbagai fasilitas sesuai peraturan perundang-undangan, dalam hal ini undang-undang tenaga kerja, sehingga karyawan diharapkan dapat bekerja dengan nyaman. 


\section{Penilaian Risiko (Risk Assessment)}

Penilaian risiko pada PT X belum dilakukan dengan baik walaupun beberapa sudah mempunyai pengendalian internal di dalamnya. Penilaian risiko terhadap siklus pendapatan atau revenue cycle antara lain dilakukan dengan membuat pemeringkatan terhadap pelanggan yang mempunyai transaksi pembelian secara kredit dengan PT X. Hal tersebut dimaksudkan untuk bahan pertimbangan dalam pemberian kredit. Namun demi mengejar target penjualan, sering kali peringkat kredit ini diabaikan sehingga mempertinggi peluang terjadinya piutang yang macet.

Selain itu, batasan kredit atau credit limit juga tidak dibuat oleh PT X. Hal itu mempertinggi peluang adanya piutang macet karena pelanggan yang sudah mempunyai saldo piutang yang tinggi masih mendapatkan piutang dari PT X. Kemudian terdapat manipulasi diskon atau potongan penjualan terhadap penjualan barang yang dilakukan dalam jumlah yang besar. Oleh karena itu, diperlukan pengendalian tambahan di dalamnya.

Pemeriksaan terhadap barang yang akan dikirimkan ke pelanggan juga menjadi masalah. Karena hal tersebut tidak dilakukan, tingkat retur penjualan yang diterima PT X cukup banyak. Memang pemeriksaan juga harus dilakukan dengan teliti ketika barang tersebut baru diterima bagian gudang saat barang tersebut diterima dari pemasok atau supplier.

\section{Aktivitas Pengendalian (Control Activities)}

Aktivitas pengendalian terkait dengan mekanisme yang memastikan bahwa semua kegiatan dan aktivitas bisnis berjalan sesuai dengan semestinya. Aktivitas dapat berupa prosedur operasional standar, kebijakan serta aturan di PT X. Dalam prosedur operasional standar yang dianalisis, PT X telah melakukan pemisahan fungsi dan pembagian wewenang yang lebih jelas lagi terlihat dalam struktur organisasi. Struktur organisasi dijadikan dasar untuk melakukan pemisahan fungsi dan pembagian wewenang.

Pemisahan fungsi yang dilakukan pada siklus pendapatan atau revenue cycle terlihat dari dipisahkannya menjadi tiga fungsi yaitu fungsi penjualan, fungsi pengelolaan piutang, dan fungsi penerimaan kas. Pemisahan ketiga fungsi tersebut merupakan bentuk pengendalian internal yang berfungsi untuk meminimalkan peluang terjadinya fraud atau kecurangan. Sistem otorisasi juga berjalan, sebagai contoh setiap pengeluaran barang harus didukung dengan adanya sales order dan surat jalan. Dengan demikian barang yang keluar dari gudang sesuai dengan pesanan dari pelanggan.

Pengendalian internal yang bersifat fisik terlihat dari digunakannya closed-circuit television (CCTV) yang merekam semua aktivitas yang dilakukan semua operasional, baik aktivitas yang bersifat operasional maupun kegiatan di manajemen. Pengendalian juga ditemukan pada aplikasi penjualan, pengelolaan piutang, dan penerimaan kas. Setiap staf yang mengakses aplikasi tersebut harus mendapatkan approval berupa username dan password.

\section{Informasi dan Komunikasi (Information and Communication)}

Semua saluran komunikasi dibuka oleh PT X. Aspirasi dari karyawan, supplier, dan pelanggan diakomodasi. Kemudian jika ada masalah dikomunikasikan secara transparan dan terbuka agar permasalahan tersebut tidak menjadi hal yang mengganjal bagi PT X di kemudian hari. Selain itu, dengan sistem aplikasi yang sudah terkomputerisasi, semua aktivitas bisnis pada siklus pendapatan telah dilaporkan dengan baik. Hal tersebut terlihat dengan adanya standar pembuatan laporan yang sudah terprogram.

Laporan-laporan tersebut dikomunikasikan sesuai dengan jenjang di dalam struktur organisasi, sebagai bahan pengambilan keputusan bagi manajemen. Kualitas laporan juga menjadi perhatian 
karena kesalahan kebijakan yang diambil juga dapat disebabkan laporan-laporan dalam manajemen yang digunakan sebagai bahan pengambilan keputusan menpunyai kualitas yang kurang memadai, baik dari segi bentuk laporan kemudian format laporan serta validasi data yang menjadi bahan pembuatan laporan-laporan tersebut.

Perhitungan bonus karyawan yang didasarkan atas target kinerja dari masing-masing karyawan juga dibuka secara transparan. Setiap karyawan dapat mengetahui tingkat pencapaian target dan dapat menghitung bonus yang akan diperoleh. Oleh karena itu, setiap karyawan merasa transparansi atau keterbukaan yang ada di PT X sudah cukup baik.

\section{Pemantauan (Monitoring)}

Pemantauan dilakukan di semua level organisasi pada PT X. Pengawasan atau pemantauan langsung dilakukan setiap atasan terhadap bawahannya pada semua level organisasi. Selain itu, kepada antarstaf dilakukan juga pengawasan. Hal tersebut sering dikomunikasikan kepada semua karyawan, bahwa mereka harus saling mengawasi dan mengingatkan agar tidak melakukan penyimpangan serta pelanggaran aturan yang telah ditetapkan oleh organisasi. Adanya pengawasan tersebut diharapkan dapat meminimalkan terjadinya fraud atau kecurangan. Sebagai tambahan, pengawasan dilakukan juga dengan menggunakan CCTV untuk memantau aktivitas yang berlangsung di PT X. Kekurangan yang ada adalah tidak adanya fungsi audit internal yang khusus memeriksa secara periodik jalannya operasional bisnis dan kinerja semua fungsi yang ada pada PT X.

\section{SIMPULAN}

Berdasarkan evaluasi yang dilakukan melalui wawancara, observasi, dan kuesioner dapat disimpulkan bahwa secara umum pengendalian internal di siklus pendapatan atau revenue cycle yang terdapat di PT X sudah cukup baik. Namun demikian masih ada hal-hal yang perlu menjadi perhatian bagi manajemen. Siklus pendapatan pada suatu organisasi atau entitas bisnis merupakan motor penggerak pengahasil mendapatan yang secara langsung memengaruhi kinerja keuangan dari PT X.

Pengendalian internal sudah baik diterapkan pada PT X, seperti prosedur yang sudah ada, pembagian wewenang dan struktur organisasi yang jelas, fungsi pengelolaan piutang yang ketat serta fungsi penerimaan kas yang mengikuti prosedur. Selain pengendalian internal yang baik, masih terdapat juga beberapa kelemahan pada pengendalian internal di PT X. Kelemahan-kelemahan tersebut antara lain: belum jelasnya mekanisme pemberian diskon pada penjualan dalam jumlah besar, tidak adanya pengecekan kualitas barang yang akan dikirim menyebabkan tingkat retur penjualan yang cukup tinggi, pemeringkatan kredit yang tidak konsisten dalam memberikan kredit kepada pelanggan. Selain itu, belum adanya mekanisme batasan kredit atau credit limit juga menjadi hal yang masih menjadi kelemahan pada pengendalian internal terhadap siklus pendapatan di PT X.

Solusi yang dapat diterapkan PT X untuk memperbaiki hal-hal yang masih menjadi kelemahan dalam pengendalian internal pada siklus pendapatan di PT X antara lain adalah membuat prosedur pemberian diskon jika ada penjualan khusus. Prosedur tersebut mengharuskan staf penjualan untuk mendapatkan otorisasi dari manajer penjualan. Kemudian solusi lain yaitu menyusun aturan yang mengharuskan barang dicek ketika akan masuk gudang maupun barang keluar gudang. Hal tersebut untuk meminimalkan tingkat retur yang cukup tinggi. Selain itu PT X harus konsisten menerapkan peringkat kredit yang ada karena hal tersebut dapat meminimalkan kemungkinan adanya piutang tidak tertagih. Terakhir, PT X membuat aturan batasan kredit untuk mencegah risiko piutang tidak tertagih dari pelanggan atau klien. 


\section{DAFTAR PUSTAKA}

Agoes, S. (2012). Auditing: Pemeriksaan Akuntan oleh Akuntan Publik. Jakarta: Lembaga Penerbit Fakultas Ekonomi Universitas Indonesia.

Arens, A. A., Elder, R. J., Beasley, M. (2012). Auditing and Assurance Services: an Integrated Approach. New Jersey: Pearson Education.

Bodnar,G. H., and Hopwood,W. S. (2010). Accounting Information Systems. New Jersey: Pearson Education.

Boynton,W. C., dan Johnson, R. N. (2006). Modern Auditing:Assurance Services and The Integrity of Financial Reporting. New York: John Wiley \& Sons.

Mariani,V., dan Permatasari, S. (2011). Evaluasi Sistem Akuntansi Penjualan Kredit, Piutang, dan Penerimaan Kas Pada PT Insan Media Pratama. Jurnal Comtech.Vol. 2 No 1. pp. 273 - 283.

Romney, M. B., dan Steinbart, P. J. (2009). Accounting Information System. New Jersey: Prentice Hall.

Weygandt, J. J., Kimmel, P. D., Kieso, D. E. (2011). Financial Accounting:IFRS Edition. New York: Wiley. 